Historia Slavorum Occidentis

2020, $\mathrm{nr} 1$ (24)

ISSN 2084-1213

DOI: $10.15804 /$ hso200103

Dorota ŻoŁąDź-STRZELCZYK

ORCID 0000-0002-4075-3002

\title{
„O porządku w naukach i sposobie wychowania" - Konsyderacyje dla Janusza Radziwiłła z roku 1622
}

Słowa kluczowe: instrukcje wychowawcze, edukacja szlachty, rodzina Radziwiłłów, podróże edukacyjne

Keywords: educational instruction, nobility’s education, Radziwiłł family, educational travels

Abstract: Krzysztof Radziwiłł's instructions on education include an indication that his son, the prince, should not go to a school abroad but rather study at home. When got older he would acquire basic knowledge and would be ready to leave. The source contains considerations on how to organize teaching, the curriculum and where to recruit the teachers.

\section{Wprowadzenie}

Wśród kilku instrukcji wychowawczych związanych z osobą Janusza Radziwiłła (1612-1655) spisanych z inicjatywy lub osobiście przez jego ojca Krzysztofa (1585-1640) znajduje się interesujący tekst zatytułowany Konsyderacyje strony wysłania księcia Janusza do cudzej ziemi. Pociechy i pożytki, dla których Książe JeM jednego syna majac kosztem $i[z]$ asystencyja niemała, umyślit go prędko $w$ tę drogę wyprawićl. Jest to tekst wyjątkowy zaważywszy na zawarte w nim rozważania sprowadzające się

1 AGAD AR XI, 37, s. 310-317. 
do tego, aby księcia ze względu na zbyt młody wiek i słabe zdrowie nie wysyłać za granicę, tylko zostawić i uczyć w ojczyźnie.

Omawiane wskazówki znajdują się w Archiwum Głównym Akt Dawnych, w Archiwum Radziwiłłów XI, nr 37, s. 310-317. Znaczne ich fragmenty zamieścił Henryk Wisner w swoim artykule o latach szkolnych Janusza Radziwiłła ${ }^{2}$. Po litewsku fragmenty wydane zostały w antologii źródeł z XIII-XVII w. ${ }^{3}$ Całość opublikowano $\mathrm{w}$ tomie instrukcji rodzicielskich z XVI-XVII w. ${ }^{4}$

Krzysztof Radziwiłł ze związku z Anną z Kiszków miał sześcioro dzieci ${ }^{5}$, ale zaledwie dwoje - Janusz i Katarzyna (1614-1674) - przeżyło niebezpieczeństwa wieku dziecięcego. Było to zjawisko typowe dla tych czasów, duża śmiertelność dzieci spowodowana rozmaitymi czynnikami przyczyniała się do tego, że dorosłości dożywało zaledwie $35 \%$ populacji ${ }^{6}$. W tym też kontekście nie dziwi staranność, z jaką książę planował i organizował opiekę nad dziećmi i wychowanie syna. Wskazówki z tym związane pozostawił Radziwiłł w korespondencji, testamencie spisanym w 1619 r., w specjalnych wytycznych redagowanych w związku z jego licznymi wyjazdami, wreszcie w zachowanych instrukcjach wychowawczych powstałych z jego inicjatywy i pod jego czujnym okiem, o czym świadczą korekty i dopiski sporządzone własnoręcznie przez księcia ${ }^{7}$. Pierwsza to powstała prawdopodobnie w $1622 \mathrm{r}$. instrukcja będąca przedmiotem rozważań niniejszego studium, następnie wskazówki spisane przed 1624 r. w związku z wysłaniem Janusza do szkoły w ojczyźnie, adresowane do

2 H. Wisner, Lata szkolne Janusza Radziwitta. Przyczynek do dziejów szkolnictwa kalwińskiego na Litwie w pierwszej połowie XVII wieku, Odrodzenie i Reformacja w Polsce 14 (1969), s. 187-188.

3 Anoniminis traktatas „Apmąstymai apie kunigaikščio Jonušo Radivlos išsiuntimą i svetima žemę” (Ištraukos), [w:] Lietuvos mokykla ir pedagoginè mintis XIII-XVII a. Istorijos šaltinių antologija, wyd. K. Grigas, V. Kryževičius, I. Lukšaitè, Vilnius 1994, s. 307-313.

4 Ojcowskie synom przestrogi. Instrukcje rodzicielskie (XVI-XVII w.), wstępem i objaśnieniami opatrzyły D. Żołądź-Strzelczyk i M.E. Kowalczyk, Wrocław 2017, s. 187-197.

5 H. Wisner, Radziwitt Krzysztof, [w:] PSB, t. 30, Wrocław 1987, s. 282.

6 Por. D. Żołądź-Strzelczyk, Dziecko w dawnej Polsce, Poznań 2002, s. 25.

7 D. Żołądź-Strzelczyk, Wskazówki wychowawcze dla Janusza Radziwitta, syna Krzysztofa, [w:] tejże, „Pod każdym względem szlachetne ci daję wychowanie...” Studia z dziejów wychowania szlachty w epoce staropolskiej, Wrocław 2017, s. 99-116. O wychowaniu dzieci w rodzinie Radziwiłłów por. U. Augustyniak, Wychowanie młodych Radziwitłów na dworze birżańskim w XVII wieku, [w: ] Od narodzin do wieku dojrzałego. Dzieci i młodzież w Polsce, cz. 1, Od Średniowiecza do wieku XVIII, red. M. Dąbrowska, A. Klonder, Warszawa 2002, s. 129-148; U. Augustyniak, The upbringing of the young Radziwills in the 17th century, Acta Poloniae Historica 79 (1999), s. 63-83. 
jego opiekuna Adama Steckiewicza (zm. 1624) oraz trzy (lub cztery $\left.{ }^{8}\right)$ instrukcje związane z rozpoczętą w 1628 r. podróżą edukacyjną książęcego jedynaka9

Celem niniejszych rozważań jest przedstawienie poglądów zawartych w omawianym źródle, które z jednej strony odbiegają od prezentowanych zazwyczaj w tego rodzaju zapisach, z drugiej zaś zawierają interesujące, przemyślane zalecenia odnośnie edukacji młodego Radziwiłła, dzięki której będzie on odpowiednio przygotowany do dalszych etapów zdobywania wiedzy i niezbędnych umiejętności. Autor tekstu znał zwyczaje związane z edukacją w szkołach krajowych i zagranicznych, dostrzegał pozytywne i negatywne strony wyjazdów na naukę w cudzych krajach, czy w podróże edukacyjne. W swoich rozważaniach pokazal, jak i gdzie powinna odbywać się edukacja młodego księcia, w jaki sposób ją zorganizować, aby przynosiła korzyści nie tylko Januszowi, ale również innym młodym ludziom $\mathrm{z}$ otoczenia księcia.

Zasadniczy kierunek wychowania syna zarysował Krzysztof Radziwiłł w testamen$\mathrm{cie}^{10}$. Podkreślał w nim, co czynił również później w instrukcjach, że nie chce, aby syna przemęczano naukami, aby „go nazbyt głębokimi naukami onerowano, bo te scholastica zacnym ludziom mało są użyteczne”. W jednej z instrukcji napisał wręcz ,ja go szkolnym doktorem mieć nie chcę, ale dobrym politykiem i dobrym ojczyznej synem"11. Kilkustopniowa edukacja zalecana w zapisie ostatniej woli Krzysztofa obejmowała naukę domową, naukę w szkole na ziemiach niemieckich od dziesiątego do siedemnastego roku życia, następnie cztery lata poświęcone edukacji wojskowej lub pobytowi na dworze monarszym. Ukoronowaniem miała być podróż edukacyjna. Syn miał się udać „na peregrynację do cudzych ziem. Którą to najlepiej incognito odprawować i dla większego bezpieczeństwa, i dla snadniejszego przypatrzenia się rzeczom wszystkim, i dla ćwiczenia rozmaitego, i dla wielu innych, których trudno wyliczyć, przyczyn"12. Taka kilkustopniowa edukacja charakterystyczna była dla szlachty tego czasu w całej

8 Czwarta instrukcja związana z podróżą Janusza to powstała w 1632 r. Informacja studze mojemu urodzonemu panu Aleksandrowi Przypkowskiemu, są to uwagi przeznaczone dla syna w związku z powierzoną mu przez króla Władysława IV misją. Wskazówki te znajdują się w AGAD AR XI, 37, s. 336-345.

9 Por. K. Radziwiłl, Wskazówki związane z edukacją syna Janusza w ojczyźnie i w cudzej ziemi (1622-1628), [w: ] Ojcowskie synom przestrogi, s. 175-244.

10 Por. Testament Krzysztofa Radziwitla, hetmana polnego litewskiego, [w: ] U. Augustyniak, Testamenty ewangelików reformowanych w Wielkim Księstwie Litewskim, Warszawa 2014, s. 166-183, uwagi dotyczące edukacji Janusza, s. 173-175.

11 Informacyja ode mnie Krzysztofa Radziwitta księcia, [w: ] Ojcowskie synom przestrogi, s. 199.

12 Testament Krzysztofa Radziwitta, s. 174-175. 
prawie Europie $^{13}$. Charakterystyczne było to, że ojciec napisal/podyktowal specjalne wskazówki na poszczególne etapy edukacji, skierowane do opiekunów syna, w końcu do niego samego. Co interesujące, książę był otwarty na argumenty innych dotyczące tego, co dla jego jedynaka będzie najlepsze. Mimo że pierwotnie planował wysłać syna na nauki za granicę w stosunkowo młodym wieku, to jednak nie zrobił tego. Być może przekonał go autor Konsyderacyji i zmienił swoje zamierzenia.

Janusz urodził się w 1612 r., zgodnie z planami ojca zawartymi w testamencie w 1622 r. powinien wyruszyć do zagranicznej szkoły. W tym mniej więcej czasie powstała omawiana instrukcja. Dokładnej daty jej powstania nie znamy, wskazówki nie są niestety datowane, nie podano w nich również nazwiska autora, którego jak dotąd nie udało się jednoznacznie ustalić.

\section{Czas powstania Konsyderacyji}

Henryk Wisner uważał, że wskazówki te napisano w 1622 r. $^{14}$, z kolei Marian Chachaj przypuszcza, że powstały w 1624 r. Nawiązuje przy tym do listu Fabiana Czemy do Krzysztofa Radziwiłła ze Sztumu z września 1624 r. List ten dotyczy wstrzymania wyjazdu Janusza z powodu panującej w Prusach zarazy ${ }^{15}$ i może dotyczyć ogólnych planów ojca, który cały czas myślał o odpowiednim wychowaniu jedynaka, uwzględniając zagraniczne nauki.

Wydaje się bardziej prawdopodobne, że omawiane wskazówki napisano w 1622 r. Świadczy o tym kilka przesłanek. Po pierwsze, zapis w testamencie Krzysztofa Radziwiłła, który zalecał, aby Janusza wysłać do szkoły w Niemczech jak skończy 10 lat, co przypadało właśnie na 1622 r. Nie uczyniono tego, a powodem mogła być zmiana decyzji ojca pod wpływem argumentów zawartych w Konsyderacyjach. Tekst mógł być rezultatem dyskusji na ten temat.

Po drugie, świadczą o tym pewne wzmianki w tekście Konsyderacyji mogące pomóc w ich datowaniu. Autor wspomina „wojnę z Gustawusem” ${ }^{16}$. Chodzi

13 Por. D. Żołądź, Ideały edukacyjne doby staropolskiej. Stanowe modele i potrzeby edukacyjne szesnastego i siedemnastego wieku, Warszawa-Poznań 1990, s. 37-82.

14 Por. H. Wisner, Lata szkolne Janusza Radziwitta, s. 188.

15 M. Chachaj, Zagraniczna edukacja Radziwittów od początku XVI do połowy XVII wieku, Lublin 1995, s. 136, przyp. 3.

16 Konsyderacyje strony wystania księcia Janusza do cudzej ziemi. Pociechy i pożytki, dla których Książe JeM jednego syna mając kosztem i $z$ asystencyja niemata, umyślit go prędko w tę drogę wyprawić, [w: ] Ojcowskie synom przestrogi, s. 189. 
zapewne o wojnę polsko-szwedzką toczącą się w latach 1621-1626. Pierwszy jej etap zakończony został zawieszeniem broni (10 VIII 1622), a następnie rozejmem (1623) obowiązującym do marca 1625 r. Drugi etap przypadł na lata 1625-1626. Przemawia to za rokiem 1622 jako czasem powstania omawianego źródła, $\mathrm{w}$ tym bowiem okresie miały miejsce działania wojenne, w związku z czym zapis o „wojnie z Gustawusem” byłby logiczny. Można nawet jeszcze przybliżyć moment powstania instrukcji. Biorąc pod uwagę wspomniany rozejm z sierpnia $1622 \mathrm{r}$. została ona napisana przed tym miesiącem, być może około połowy 1622 r., raczej nie wcześniej. Janusz urodził się w grudniu 1612 r. nie sądzę, aby książę już w $1621 \mathrm{r}$. planował jego wyjazd, byłoby to sprzeczne z założeniem przedstawionym $\mathrm{w}$ testamencie o wysłaniu syna w wieku 10 lat.

Po trzecie, w tekście pojawia się wzmianka o Gaborze Bethlenie, czytamy „ale iż się jeszcze wojny w tamtych krajach nie uspokoiły, a strzeż się Boże, kiedy by Gabor Betlema znieść mieli” ${ }^{17}$. Wynika z tego, że do autora nie dotarła jeszcze wiadomość o klęsce powstańców węgierskich pod Ołomuńcem (listopad 1621) i zawarciu pokoju z cesarzem Ferdynandem II Habsburgiem 6 I 1622 r., co sugeruje, że instrukcja powstała nie później niż w tymże roku.

Wszystkie te uwagi świadczą, że omawiany tekst nie został napisany przed $1622 \mathrm{r}$. i nie później niż w tym właśnie roku, najprawdopodobniej datować go należy na pierwszą połowę lub połowę tego roku.

\section{Kwestia autorstwa}

Kolejny problem dotyczy autora Konsyderacyji. Wskazówki nie są podpisane, nie ma w nich również bezpośrednich odniesień do osoby autora. Pozostają próby ustalenia przypuszczalnego autora na podstawie pośrednich informacji zawartych w omawianych rozważaniach. Henryk Wisner brał pod uwagę Adama Rassowskiego ${ }^{18}$, ewentualnie Samuela Przypkowskiego ${ }^{19}$, natomiast Marian Chachaj sądzil, że mógł to być Daniel Naborowski ${ }^{20}$, ale nie potwierdza tego, według niego, analiza pisma. $Z$ tekstu wynikają następujące wnioski: autor doskonale orientował się w ówczesnej sytuacji

17 Tamże.

18 M. Chachaj, Zagraniczna edukacja, s. 186.

19 H. Wisner, Janusz Radziwitt 1612-1655 wojewoda wileński, hetman wielki litewski, Warszawa 2000, s. 14.

20 M. Chachaj, Zagraniczna edukacja, s. 75. 
politycznej, znał zapewne z własnego doświadczenia wiodące ośrodki akademickie, odpowiadające księciu pod względem wyznania, znał realia życia za granicą, szczególnie od strony finansowej, ale nie tylko. Ponadto znał dobrze małego księcia, wiedział o jego słabościach, „ciele subtelnym podległym wszelakim alteracyjom”, ale znał także jego zdolności - „książę Janusz snadnie [...] ma z laski Bożej iudicium dobre"21. Miał również pewną wiedzę o krewnych księcia, znał sytuację związaną $\mathrm{z}$ opieką nad księciem Bogusławem, którym zgodnie z testamentem ojcowskim miał opiekować się Krzysztof, a tymczasem matka wywiozła go poza granice Litwy. Niewątpliwie musiał być to ktoś pozostający w bliskich kontaktach z Radziwiłłami, znający dobrze Janusza i poglądy księcia. Jednocześnie ktoś na tyle ważny dla Radziwiłła, że mógł wpłynąć na zmianę jego decyzji.

Adam Rassowski przybył do Kojdanowa, gdzie przebywał Janusz Radziwiłł jesienią 1621 r. Chłopiec w liście do ojca z listopada tego roku pisał w związku z jego osobą „za przysłanie Pana Rassowskiego do mnie wielce dziękuję, gdyż mając człowieka uczonego przy sobie rozumiem, że sproszym krokiem w zawodzie nauk będę móg1 postępować"22. Jego przybycie zapoczątkowało regularną naukę chłopca. Według Wisnera za autorstwem Rassowskiego przemawia „przebijająca z tekstu znajomość zamiłowań chłopca i słabostek, a także troska autora o wychowanie młodego Radziwiłła na człowieka oddanego sprawom kościoła kalwińskiego"23, przeciwko natomiast - zbyt dobra orientacja w sprawach rodzinnych Radziwiłłów, co według Wisnera nie pasuje do „skromnego nauczyciela szkoły birżańskiej”. Ponadto nie wydaje się, aby Rassowski miał tak dobrą orientację w sytuacji politycznej w Europie. Tak więc mimo że wiele przemawiałoby za jego autorstwem, należy tę wersję odrzucić.

Kolejny kandydat, Samuel Przypkowski (1592-1670) ${ }^{24}$, związany był z dworem Krzysztofa od około 1621 r. Wcześniej uczył się przez kilka lat za granicą, najpierw w Altdorfie, następnie w Lejdzie, który to ośrodek został wspomniany w omawianym tekście. Odwiedził również Londyn i Paryż. Znajomość z księciem Radziwiłłem zawarł prawdopodobnie jeszcze podczas pobytu za granicą. Cieszył się jego dużym zaufaniem, Radziwiłł określał go w listach „sługa mój p. Przypkowski”25. W okresie

\footnotetext{
21 Konsyderacyje, s. 193.

22 AGAD AR IV, sygn. 176, s. 3.

23 H. Wisner, Lata szkolne, s. 186.

24 Z. Ogonowski i J. Tazbir, Przypkowski Samuel, PSB, t. 29, Wrocław-Warszawa-Kraków-Gdańsk 1986, s. 227-232.

25 Tamże, s. 227.
} 
bezpośrednio przed powstaniem omawianego tekstu Przypkowski wiele podróżował wykonując polecenia księcia, m.in. w $1621 \mathrm{r}$. uczestniczył w pertraktacjach z elektorem pruskim Jerzym Wilhelmem i w związku z tym przebywał w Królewcu. Te podróże i kontakty międzynarodowe z pewnością dały mu orientację w tym, co ówcześnie działo się w Europie, a taką wiedzę posiadał z pewnością autor omawianego źródła. Za autorstwem Przypkowskiego przemawiają zatem następujące argumenty: zaufanie księcia, wykształcenie, orientacja w sytuacji międzynarodowej.

I wreszcie trzeci możliwy autor Konsyderacyji Daniel Naborowski (1573-1640), wykształcony za granicą, uczył się w latach 1593-1602 w Wittenberdze, Bazylei, Orleanie, Strasburgu, Padwie ${ }^{26}$. Związany był najpierw ze starszym, przyrodnim bratem Krzysztofa, Januszem. Towarzyszył mu w emigracji i podróżach dyplomatycznych. Po śmierci Janusza, pod koniec 1620 r. przeszedł na służbę Krzysztofa Radziwiłła. Wielokrotnie załatwiał $\mathrm{w}$ imieniu księcia rozmaite sprawy poza granicami, m.in. dotyczące wdowy po Januszu i małego Bogusława. Problemy edukacji młodych ludzi nie były mu obce. Swoje związki z Radziwiłłami rozpoczął m.in. od uczenia Janusza, starszego syna Pioruna, języków obcych ${ }^{27}$. Przez pewien czas zajmował się edukacją Bogusława Radziwiłła (1620-1669) ${ }^{28}$. Wątki pedagogiczne pojawiają się również w jego wierszach. Pozostający na służbie Radziwiłłów pisarze prowadzili korespondencję książęcą, przygotowywali okolicznościowe oracje, pisali na zlecenie swych patronów pamiętniki, diariusze, relacje z poselstw ${ }^{29}$. Naborowski występował niekiedy jako sekretarz Krzysztofa Radziwiłła w czasie, kiedy był jeszcze na służbie Janusza, a w okresie późniejszym książę często korzystał z pomocy poety. Obok obowiązków sekretarskich powierzał mu rozmaite misje dyplomatyczne, funkcje na dworze, m.in. marszałka dworu ${ }^{30}$.

Wśród wielu osób pozostających na służbie Krzysztofa Radziwiłła byli jeszcze inni dworzanie, którzy mogliby być brani pod uwagę jako autorzy omawianych wskazówek. Blisko przez wiele lat związany z księciem był na przykład Piotr Kochlewski (zm. 1646), sekretarz, zaufany poseł, związany od mniej więcej 1610 r. z Radziwił-

26 P. Buchwald-Pelcowa, Naborowski Daniel, [w: ] PSB, t. 22, Wrocław-Warszawa-Kraków-Gdańsk 1977, s. 422-424.

27 M. Jarczykowa, Książka i literatura $w$ kręgu Radziwittów birżańskich w pierwszej połowie XVII wieku, Katowice 1995, s. 126.

28 J. Dürr-Durski, Daniel Naborowski. Monografia z dziejów manieryzmu i baroku w Polsce, Łódź 1966, s. 93-94.

29 Tamże, s. 100.

30 Tamże, s. 99 i n. 
łem $^{31}$. Kochlewski interesował się i mocno angażował w sprawy oświatowe, wspierał szkolnictwo kalwińskie. Podczas podróży Janusza usprawiedliwiał i bronił przed księciem jego opiekunów, którzy wbrew woli ojca zabrali młodzieńca do Altdorfu. Doradzał księciu w sprawie edukacji i decyzji o osiągnięciu lat sprawnych przez Bogusława. Jednakże aktywność Kochlewskiego na tym polu przypada na okres nieco późniejszy niż data powstania Konsyderacyji. W zachowanych źródłach w 1619 r. określony został jako pacholę Krzysztofa Radziwiłła ${ }^{32}$, raczej mało prawdopodobne, aby trzy lata później miał taki wpływ na księcia, że ten zmienił swe plany względem syna.

Zarówno Przypkowski, jak i Naborowski cieszyli się odpowiednim autorytetem i zaufaniem księcia, ich wykształcenie i obycie w świecie mogło spowodować, że Radziwiłł wysłuchał przedstawionych argumentów i zmienił decyzję w sprawie edukacji syna. Niestety na obecnym etapie trudno jest jednoznacznie stwierdzić, który $\mathrm{z}$ nich był autorem omawianych rozważań.

\section{„Pociechy i pożytki” z wyjazdów edukacyjnych}

Instrukcja ta odbiega charakterem od innych przekazów tego rodzaju. Podczas kiedy zasadniczo wskazówki związane z wyjazdami edukacyjnymi młodzieży zalecają i ukierunkowują peregrynację, $\mathrm{w}$ tym przypadku mamy do czynienia z rozważaniami pokazującymi, że w danym momencie nie należy młodego Radziwiłła wysyłać poza granice Rzeczypospolitej. Wręcz przeciwnie, autor uzasadnia dlaczego najlepiej uczyć chłopca w ojczyźnie, jakie to da, nie tylko Januszowi, korzyści.

Tekst składa się z dwóch nierównych części. Pierwsza przedstawia w punktach pożytki, które decydują o wysyłaniu młodzież na nauki za granicę. Druga natomiast pokazuje, że Janusz jest zbyt młody i jeszcze nie czas na wysłanie go do cudzych ziem na nauki. Na tę część składają się rozważania będące ustosunkowaniem się do wyliczonych na początku zalet podróżowania, następnie autor pokazuje, jak według niego powinna na tym etapie wyglądać edukacja książęcego jedynaka oraz jak i gdzie ją zorganizować.

W siedmiu punktach „pociech i pożytków” wymienione zostały powody, dla których wysyła się młodych ludzi „do cudzej ziemi”. Po pierwsze są to względy religijne, „aby za młodu, uczyło się i wprawowało panię w pobożność i prawdziwą chwałę

31 M. Jarczykowa, „Papirowe materie” Piotra Kochlewskiego. O działalności pisarskiej sekretarza Radziwittów birżanskich w pierwszej połowie XVII wieku, Katowice 2006, s. 75-80.

32 U. Augustyniak, Dwór i klientela Krzysztofa Radziwitta (1585-1640). Mechanizmy patronatu, Warszawa 2001, s. 155. 
Bożą" 33 . Motyw ten pojawia się we wszystkich instrukcjach niezależnie od wyznania ich autorów. Wychowanie religijne było nieodłącznym składnikiem edukacji tego czasu. W instrukcjach dla Janusza pochodzącego z jednego z najważniejszych rodów dawnej Rzeczypospolitej związanych z obozem reformacyjnym ten aspekt oczywiście występuje. Wszystkie instrukcje napisane dla młodego księcia o tym wspominają, ale co trzeba podkreślić, nie robią z tego jakiegoś dominującego motywu. Dla Radziwiłłów, zwolenników reformacji, szczególnie ważne było unikanie kontaktów z przedstawicielami innych wyznań. Z pewnością pamiętano o konwersji Mikołaja Krzysztofa zwanego Sierotka (1549-1616) ${ }^{34}$, który właśnie podczas młodzieńczych peregrynacji zmienił wyznanie zapoczątkowując tym samym podział rodu na część katolicką i część protestancką. Radziwiłłowie pamiętali o tym, o czym świadczą zapisy w testamentach. Krzysztof Piorun (1547-1603) zalecal, aby jego młodszy syn wydzielić przecinkami nie jeździł do Włoch „bo nie życzył bych mu, aby dla umiejętności tego języka i dla przypatrzenia się delicjom i sykofancji tamtych ludzi miał mutare, czego go Panie Boże racz uchować, religionem"35. Podobnie czynili jego synowie. Janusz (1579-1620) w zapisie ostatniej woli zalecał, aby „syn Bogusław [...] gdy tego czas będzie, ćwiczenie swe w naukach wyzwolonych nigdzie indzie tylko w szkołach i akademiach ewangelickich, od których usque ad annos discretionis odrywan być nie ma”36. I dalej zalecał „peregrynując, jeśli do tego przyjdzie, niech Włoch i Hiszpanii zaniecha, chyba by już dobrze był w religii i pobożności ugruntowany" ${ }^{37}$. Młodszy z synów Pioruna przestrzegal, aby jego syn „we Włoszech, Hiszpanii nie postawał, a pogotowiu obyczajów tamecznych strzegł się"38.

Drugi punkt mówi o tym, aby się „panię wprawowało we wszelakie cnoty i obyczaje”. Uzupełniało to wychowanie religijne w elementy wychowania moralnego, niezbędnego w kontaktach z ludźmi w ojczyźnie i poza nią. Bez tego człowiek nie mógłby funkcjonować w społeczeństwie, „musiałby nie ludzki, ale pojedynkowy,

\footnotetext{
33 Konsyderacyje, s. 187.

34 T. Kempa, Mikotaj Krzysztof Radziwitt Sierotka (1549-1616) wojewoda wileński, Warszawa 2000, s. 40 i n.

35 Testament Krzysztofa Radziwitta zw. Piorunem, wojewody wileńskiego, hetmana wielkiego litewskiego, [w:] U. Augustyniak, Testamenty ewangelików reformowanych w Wielkim Księstwie Litewskim, Warszawa 2014, s. 95.

36 Testament Janusza Radziwitta, kasztelana wileńskiego, [w: ] Testamenty ewangelików reformowanych, s. 193.

37 Tamże.

38 Testament Krzysztofa Radziwitta, hetmana polnego litewskiego, s. 175.
} 
prywatny żywot prowadzić”. Kolejna sprawa to „aby się w nauki stanowi swemu należące” wprawować, co może się dokonać podczas kontaktów z ludźmi „uczonymi i bywałymi".

Jednym z najważniejszych powodów podejmowania podróży do cudzych krajów była chęć poznawania języków obcych ${ }^{39}$, do tego nawiązuje czwarta przyczyna. „Dziecinne lata sposobniejsze są niż dorosłe” i dlatego ważne jest aby człowiek „za młodu [...] nauczył się języków cudzoziemskich”. Autor zauważa jednak, że języki „panu wielkiemu [...] raczej dla ozdoby niż dla potrzeby umieć nie wadzi”. Znajomość języków obcych uznawana była dla szlachcica za ważną, jak pisał Jakub Sobieski (1591-1646) w instrukcji spisanej, kiedy wysyłał synów do Paryża: „To ozdoba każdego slachcica polskiego i pochwała między przednimi ozdobami i pochwałami umieć języki. A nie tylko każdego slachcica polskiego, ale każdego hominis politici. Przyda się i na dworze pańskim, przyda et in Republica na różne legacje, na różne pańskie i Rzeczypospolitej usługi”40.

Piąty punkt mówi o odnowieniu znajomości zawartych przed laty przez przodków podróżnika i nawiązywaniu nowych, co „nie tylko u ludzi cudzoziemskich sławę, ale i u swego narodu reputacja jedna”. Szósty zalecał, aby „się przypatrzyło panię położeniu krajów cudzoziemskich, obyczajom różnych narodów”. Siódmy mówił o wykorzystaniu nadarzającej się okazji przypatrywania się wojsku „sposobom, fortelom rozmaitym, porządkom wojennym i inszym rzeczom do spraw rycerskich należącym”, co kiedyś może okazać się przydatne.

Jak widać, autor przedstawił względy wyznaniowe, obyczajowe, edukacyjne, towarzyskie, wreszcie poznawcze. Wszystkie mogły zostać zrealizowane podczas odpowiednio zaplanowanej i we właściwym czasie odbytej peregrynacji.

\section{Dlaczego Janusz nie powinien jeszcze wyruszać za granicę?}

Kolejną, dłuższą część rozważań autor rozpoczyna od przedstawienia przyczyn, z powodu których Janusz nie powinien jeszcze wyjeżdżać do cudzych krajów. Pierwsza

39 D. Żołądź-Strzelczyk, „Obcych języków siła umieć jest dar Boży” - XVII-wieczne poglądy na nauczanie języków, [w:] Origines, fontes et narrationes - pośród kręgów poznania historycznego. Prace ofiarowane profesorowi Marcelemu Antoniewiczowi w 65. rocznicę urodzin, red. M. Cetwiński, M. Janik, Częstochowa 2018, s. 963-974; A. Skrzypietz, Cudzoziemski „język jeśli komu tedy nam potrzebny” - „obce” i "nasze” w oczach Sobieskich, [w: Staropolski oglad świata - problem inności, red. F. Wolański, Toruń 2007, s. 162-183.

40 J. Sobieski, Instrukcja synom moim do Paryża [w:] Ojcowskie synom przestrogi, s. 315. 
przyczyna dotyczy wieku młodego Radziwiłła. Autor uznał, że jest on po prostu zbyt młody, aby wyruszać w daleką podróż. Pisze „dziecię jeszcze młode, do tego kompleksyjej subtelnej i nie bardzo dużej" i spowodowana zmianą miejsca odmiana powietrza, wody, pożywienia może się okazać dla niego szkodliwa. Mamy w tym zdaniu dwa aspekty problemu, po pierwsze wiek chłopca, po drugie jego nie najlepsze zdrowie. Jeżeli przyjmiemy, że Konsyderacyje napisano w 1622 r. Janusz miał wtedy 10 lat. Chłopcy w tym wieku wysyłani byli do szkół, najczęściej jednak do tych leżących na terenie Rzeczypospolitej. Znamy wprawdzie przypadki, kiedy rówieśnicy Janusza wyruszali do szkół w cudzych krajach, ale nie były one zbyt częste. Stanisław Lubomirski (1583-1649) wysłany został do Monachium w wieku jedenastu lat, oczywiście pod czujną opieką preceptora Jana Gębczyńskiego ${ }^{41}$. Hieronim Baliński (ok. 1540 - ok. 1600) proponował, aby chłopca wysłać pierwszy raz za granicę w wieku 12 lat ${ }^{42}$. Taki wiek uznał za odpowiedni do wysłania synów Mikołaj Krzysztof Radziwiłł zwany Sierotka. Wcześniejszych, przed dwunastym rokiem życia, wyjazdów nie pochwalał. Uważał, że „gdy nazbyt młodo dzieci wysyłają” może się zdarzyć, że zapomną one rodzimego języka. Jego synowie mieli mieć dwanaście lat, kiedy w myśl ojcowskich instrukcji, powinni jechać do szkoły w Dillingen ${ }^{43}$. Podobne ustalenia poczynione zostały odnośnie młodzieży z innych terenów. Te dotyczące podróży najwyższej grupy społecznej, przedstawicieli niemieckich rodzin książęcych pokazują, że wiek wysyłanych młodych ludzi wahał się między 12 a 24 rokiem życia ${ }^{44}$. Przy czym najmłodsi byli często wysyłani niejako dodatkowo, kiedy ich starsi bracia wyruszali do cudzych krajów, nie był to zatem zwyczajowy wiek, ale rzec można, korzystanie z okazji.

Drugim powodem przytoczonym przez nieznanego autora było zdrowie młodego Radziwiłła. O słabym zdrowiu jedynaka Krzysztof wielokrotnie wspominał w innych instrukcjach zalecając jego opiekunom szczególną troskę w tym zakresie i poszukanie odpowiedniego medyka, który czuwałby nad młodym księciem. Ojcowski niepokój z pewnością zwiększał fakt, iż Krzysztof był jedynym synem, który przeżył niebezpieczeństwa początków życia.

41 Por. W. Czapliński, J. Długosz, Podróż młodego magnata do szkót (Studium z dziejów kultury XVI i XVII w.), Warszawa 1969

42 D. Żołądź-Strzelczyk, „Wychowanie dobre dziecięciu szlacheckiemu” - Hieronim Baliński o edukacji, Biuletyn Historii Wychowania 39 (2018), s. 7-18.

43 M.K. Radziwiłł zw. Sierotka, Admonitorium, [w: ] Ojcowskie synom przestrogi, s. 85-86.

44 E. Bender, Die Prinzenreise. Bildungsaufenthalt und Kavalierstour im höfischen Kontext gegen Ende des 17. Jahrhunderts, Berlin 2011, s. 76-82. 
Kolejna przyczyna przywołana w Konsyderacjach to niebezpieczeństwa, jakie czyhają za granicą, z pewnością autor miał na myśli wydarzenia związane z toczącą się wojną trzydziestoletnią. Podróż w takich warunkach mogłaby okazać się niebezpieczna. Ponadto zważywszy na rangę rodu Radziwiłłów jego przedstawiciel z pewnością wzbudziłby zainteresowanie wrogów. Autor zastanawia się nad trasą czy miejscem nauk, ale ostatecznie odrzucił rozmaite możliwości. Pod uwagę wziął Lejdę, ewentualnie Bazyleę lub Genewę. Do pierwszego miasta, Lugdunum Batavorum, droga wiodła przez ziemie niemieckie - Hesję, Westfalię, Fryzję - a tam „wszędzie ludzie hiszpańscy leżą”. Możliwe było także dostanie się tam drogą morską, ale „na Bałtyckim Morzu pogotowiu dla Szwedów”, czyli niebezpiecznie z powodu wojsk szwedzkich. Równie niebezpiecznie było w przypadku przejazdu do Bazylei, czy Genewy, trasa wiodła przez tereny zajęte przez wojska hiszpańskie. „Na ostatek zajechawszy na miejsce żadnego bezpieczeństwa nie masz, bo wszytkie tamte prowincje i miasta nie są próżne niebezpieczeństwa od nieprzyjaciół i każde z nich swoje gwardie i żołnierstwo domowe chowa, i wielkie utrapienia od swoich i cudzych cierpią. A jako od cudzych ludzi wojennych różne zwykły przypadać niebezpieczeństwa, tak pogotowiu podczas wojny wiele się rozmaitych przypadków dzieje i od swoich, że żaden nie jest bezpieczny"45.

„A chociażby kto rzekł, że się trudno wszytkich przygód uwiarować, a bez woli Bożej nic się złego stać nie może. Prawda to, ale szczęśliwy i mądry każdy przed szkodą, a nie po szkodzie, rzeczy przyszłe upatruje. A samo myślenie, sam frasunek i ustawiczna bojaźń o jedynym synu wieleby zdrowia ująć musiało rodzicom”. Było to szczególnie istotne, że Janusz był jedynym synem, który przeżył niebezpieczeństwa dzieciństwa, jedynym dziedzicem, tym który miał kontynuować dzieło przodków.

Autora Konsyderacyji nie przekonuje nawet argument, że wyjeżdżając Janusz może się wiele nauczyć. Uważa, że „księcia Janusza w tak małych leciech, w tak subtelnym zdrowiu, do tak pełnych różnych niebezpieczeństw krajów posyłać teraz nie tylko niebezpieczno, ale mało pożyteczno". Tak wczesny wyjazd spowoduje, że Janusz będzie odbiegał pod względem wieku i poziomu wiedzy od uczniów zagranicznych szkół, którzy będą bardziej od niego „dojrzeli w leciech i w rozsądku, którzy już mają swoje w naukach progresyje" ${ }^{36}$. Tamtejsi nauczyciele przyzwyczajeni do starszych uczniów nie będą potrafili dotrzeć do chłopca, stąd musiałby on więcej uczyć się prywatnie, niż w publicznych szkołach, co pewnie nie dałoby najlepszych efek-

\footnotetext{
45 Konsyderacyje, s. 190.

46 Tamże, s. 191.
} 
tów, a zwiększyłoby koszty podróży. Nawet argument, że języków najlepiej uczyć się w młodszym wieku nie jest według autora dostatecznie przekonujący. Pożytki z tym związane nie przeważyłyby szkód. Autor zauważa, że często młodzi ludzie wysyłani na nauki za granicę, kiedy „z tamtych krajów przyjeżdżają, niewielki profect w naukach i językach przywożą, chociaż koszt wielki na nich rodzicy z urazą swoja ważyli" ${ }^{47}$.

Kolejne zalety odbywania zagranicznych nauk, takie jak ćwiczenia w cnotach czy „ponowienia przyjaźni przodków swoich”, autor również oddala. W pierwszym przypadku uważa, że najlepiej, jeżeli chłopiec nie od „hardych Hiszpanów, lekkich Francuzów ani plugawych Niemców uczyć się będzie”, ale od „narodu swego ludzi” i dalej pisze, że z „łaski Bożej ma książę Janusz, z natury i ćwiczenia młodego, piękne początki wszelakich cnót i obyczajów, nie cudzoziemskich nieszczyrych ani ofertowych, ale ojczystych szczyrych z przystojną prezencyją, stanowi swemu należącą" ${ }^{3}$. W drugim zaś Janusz jest zbyt młody, to dziecko jeszcze, nie będzie więc partnerem dla znajomych ojca czy dla tych, z którymi jemu wypadałoby zawierać znajomości lub przyjaźnie. Zbyt młody wiek Janusza nie pozwoli mu również odbywać ćwiczeń rycerskich, dotyczy to zarówno jego sił fizycznych, jak i zdolności pojmowania i zapamiętywania. Cóż bowiem z tego, że zobaczy różne rzeczy, które mogłyby się przydać, jak tego przez „małe lata pojąć nie może, ani o tym iudicium ferować a pogotowiu pamiętać nie będzie" 49 .

\section{„Lepszy sposób do ćwiczeń i nauk”}

Autor wskazówek nie poprzestaje na wskazaniu argumentów przeciwko wysłaniu Janusza za granicę, „nie dość zganić teraźniejszą w małych leciech wyprawę księcia Janusza w tamte kraje - pisze - jeśliby się lepszy sposób do ćwiczenia i nauk jego nie ukazał, któremu tego obojga pilna potrzeba, przetoż z miłości mojej ku chwale Bożej, ku ojczyźnie, i ku panięciu, który ma być nie tylko na pociechę rodzicom swoim, ale na rozmnożenie chwały Bożej, na usługę i ratunek ojczyzny, a na ozdobę familijej swojej wychowany. Taki sposób chowania i ćwiczenia zda się być dobry" ${ }^{\text {"0 }}$. I w dalszej części swoich rozważań pokazuje, co według niego powinno się w tym

\footnotetext{
47 Tamże.

48 Tamże.

49 Tamże, s. 192.

50 Tamże.
} 
zakresie uczynić. Proponuje przede wszystkim, aby Janusz uczył się w ojczyźnie. To tutaj najlepiej można kształtować jego pobożność, przekazywać wiedzę czy ćwiczyć ciało, wprawiając go w jeździe konnej, szermierce itp. „Nauki stanowi jego należące, w tych leciech z większym progresem w ojczyźnie, w majętności której na miejscu mieszkając, odprawować może, niż w cudzej ziemi, a bez myślenia i frasunku rodzicielskiego o niebezpieczeństwie zdrowia jego, krom tak wielkiego nakładu, jaki by w cudzych ziemiach musiał być" 51 . Po kolei przedstawione zostały korzyści nauk na terenie Rzeczypospolitej.

Istotne w edukacji staropolskiej wychowanie religijne, ksztaltowanie w „prawdziwej pobożności” najlepiej można realizować w ojczyźnie. Kazania głoszone w „wyrozumianym języku” i w tym samym odprawowanie nabożeństw są lepsze dla dziecka niż te „w cudzej ziemi” głoszone w obcych językach. Janusz musiałby tam „długo [...] w kościele siadać, nic nie rozumiejąc, jako na niemieckim kazaniu, a częstokroć patrząc na wiele rozmaitych obrzędów i różnic, których w tamtych krajach w nabożeństwie dosyć, obawiać się, aby miasto zbudowania, zgorszenie nie nastąpiło" ${ }^{22}$. Dostrzec można w tych słowach obawę przed zagrożeniem odstępstwem, co jak wspomniano miało w tej rodzinie miejsce. Przykładny kaznodzieja, kontrola rodzicielska, uchronienie przed wpływami bałwochwalców, ganienie „wszytkich zabobonów" wszystko to miało zabezpieczyć Janusza przed złymi wpływami w tym zakresie.

Po względach wyznaniowych omówione zostały nauki potrzebne Januszowi. Autor wskazówek, podobnie jak książę, nie był zwolennikiem uczenia dziecka zbyt wielu rzeczy. Obaj uważali, że nie należy przeciążać umysłu chłopca „mordując go gramatyką, dialektyką albo retoryką". Ważne jest, aby ustawicznie ćwiczył się w języku łacińskim. Należało poszukać takich nauczycieli, którzy by „inaczej jedno po łacinie z nim nie mówili, wprawować go, aby mógł expedite mówić, czasu potrzeby napisać, a nade wszytko, którego by kolwiek autora czytał, aby mógł rozumieć bez tłumacza. A z ustawicznego używania i częstego czytania snadnie się łacińskiego języka nauczyć może" ${ }^{53}$. W dalszej kolejności młody Radziwiłł powinien uczyć się historii, polityki i matematyki. Autor uznał je za nauki bardzo potrzebne, chociaż „naród nasz pogardza” nimi. Nauka ich nie powinna sprawiać bystremu chłopcu, jakim był Janusz, specjalnych trudności, ponieważ są to nauki „zabawne i ucieszne”,

\footnotetext{
51 Tamże, s. 194.

52 Tamże, s. 192-193.

53 Tamże, s. 193.
} 
a ponadto „mając kondyscypułów do tego sposobnych, grając i zabawiając się tym snadnie, wiele rzeczy potrzebnych pojąć może" ${ }^{54}$. Autor sugeruje, jak można sądzić po tych słowach, aby podczas nauki wykorzystywać zabawy i gry z rówieśnikami, co spowoduje, że chłopiec chętniej, łatwiej będzie zdobywał wiedzę.

Młody Radziwiłł miał uczyć się języków - „co się tknie ćwiczenia w językach, tych nad łaciński, niemiecki, a węgierski, jako sąsiad ojczyźnie przyległych, mało więcej potrzeba i w tych może doma dobre początki wziąć, mając na to z młodzi odłączone i pewne godziny naznaczone, których by tym się samym zabawiali" 55 .

Obok kształcenia umysłu zalecane były także ćwiczenia fizyczne, takie jak jeżdżenie na koniu czy szermierka. Należało „chować przy nim zawsze kawalkatora dobrego i koni jezdnych kilkadziesiąt, aby i konie ćwiczenie swoje miały i młódź ta, która będzie przy Januszu, aby się ćwiczyła i panię, aby się przypatrywało" ${ }^{56}$. Autor wskazówek uważał, że chłopiec jazdę konną ma w swojej naturze, ale powinien „powoli według sił i ćwiczenie może brać”. Ważne były również ćwiczenia szermierskie „w które aby się książę Janusz, według sił swoich, pomału wprawował, czasów i godzin od nauk wolnych, miasto rekreacyjej tego zażywać może, a przy tym i młódź, która by była przy nim, ćwiczyłaby się”. Inne zajęcia „choć uczciwe, ale iż mało potrzebne i pożyteczne" spokojnie mogą zostać pominięte. Autor miał na myśli muzykę, skakanie, tańce. Młody Radziwiłł, co dostrzegł autor, miał pewne skłonności, być może zdolności do malowania. Można mu na to pozwolić, nawet zatrudnić nauczyciela. Wtedy chłopiec takimi zajęciami będzie wypełniał czas wolny, „miasto inszych niepotrzebnych zabaw".

Ponieważ Janusz miał pewne trudności z przemawianiem, a umiejętność ta była w jego późniejszym publicznym funkcjonowaniu niezbędna, należało starać się „wprawować w publiczne dysputacyje, w publiczne oracyje, czasem komedyje” dając mu odpowiedniego nauczyciela retoryki.

Po omówieniu zakresu nauk i umiejętności, które młody Radziwiłł powinien posiąść, Autor Konsyderacyji przechodzi do pokazania, jak konkretnie nauka Janusza powinna wyglądać, jak ją zorganizować.

Nauka chłopca na tym etapie powinna, jak wiemy, odbywać się w ojczyźnie. Najlepiej byłoby gdyby młody Radziwiłł zamieszkał „w majętności której na miejscu”, gdzie „powietrze zdrowe, mieszkanie wczesne, dostatki i wychowanie przystojne”,

54 Tamże.

55 Tamże, s. 195.

56 Tamże, s. 194. 
gdzie chłopiec mógłby nie tylko spotykać się z rodziną, przyjaciółmi i znajomymi, ale także „na sejmik blisko przyległy jechać, krótkimi słowy perorować, ludzi poznawać i miłość sobie jednać ludzkością i chlebem"s7.

Dla lepszej nauki można sprowadzić uczonych ludzi, którzy mogliby przekazywać jemu i innymi przy okazji młodzieńcom wiedzę skuteczniej niż podczas pobytu za granicą. Były to „czasy wojenne” i prawdopodobnie łatwo będzie znaleźć dobrych nauczycieli, których niebezpieczeństwa wojen zmusiły do opuszczenia domów lub szkół, gdzie pracowali. Autor Konsyderacyji uważa, że gdyby dla młodego Radziwiłła sprowadzono nauczycieli, to przy nim mogłaby się również uczyć „młódź szlachecka”. Wkrótce zapewne wokół niego powstałaby swoista szkoła. „A kiedy by było wolno i obcym tam przyjeżdżać, lekcyji słuchać i tych inszych nauk i ćwiczenia zażywać, wiele by się i z obcych szkół dziatek szlacheckich tam garnęło i wielkie by rozmnożenie kościoła Bożego rosło i animusze młodzi szlacheckiej ku książętom wprawowały by się w miłość, a sława nie tylko w ojczyźnie, ale i w cudzych krajach wielka by, o tak zacnem wychowaniu syna książęcego, była" ${ }^{58}$. W źródle pojawiają się nazwiska rodów spokrewnionych, spowinowaconych, zaprzyjaźnionych z Radziwiłłami, które zapewne przysłałyby swoich synów, aby wspólnie z synem księcia pobierali nauki, co pozwoliłoby im uniknąć wysokich kosztów edukowania synów w cudzych krajach. Wspomniani zostali Gorajscy, Dorohostajscy, a także kuzyn Janusza, Bogusław Radziwiłł pozostający pod opieką stryja, który uczyłby się w tym miejscu jeszcze w czasie, kiedy Janusz ruszyłby już na zagraniczne peregrynacje.

W tekście poruszony został jeszcze jeden istotny wątek, strona finansowa wyjazdów zagranicznych. Autor szacuje, ile mogłoby kosztować sprowadzenie nauczycieli. Według niego byłoby to „najwięcej pięć tysięcy złotych, albo i mniej”, wszak jeden nauczyciel może nauczać kilku przedmiotów. I proponuje, aby „dwiema starszym po tysiącu złotych, trzeciemu kilkaset, kawalkatorowi tysiąc, szermierzowi kilkaset, aż to nie uczyni cztery tysiące, aż nakładem na przyprowadzenie ich piaty tysiąc, albo mało co nadto" 59 .

W przypadku wyjazdu przedstawiciela tak znacznego rodu towarzyszyć mu powinien odpowiedni orszak, ponadto jego życie w cudzych krajach powinno oddawać świetność rodu. Wszystko to pociągnąć musiało za sobą znaczne koszty. „Mieszkanie w cudzej ziemi, z płaceniem starszym i młodszym, którzy by tam jechali, z odziewa-

57 Tamże.

58 Tamże, s. 195.

59 Tamże, s. 196. 
niem cudzoziemskim, które wiele kosztuje, z mieszkaniem i wychowaniem jeśli nie więcej a pewnie na rok, będzie kosztowało dwadzieścia tysięcy złotych. A poglądając jako tu u nas, a jako tam pieniądze idą, jako je trudno i niebezpieczno przesyłać, jako wiele na poczty, na weksel, na podarki różnym osobom, w tamtych krajach między panięty zwyczajne wychodzi i dobrze większą sumę na rozchód uczyni”" ${ }^{60}$. Janusz musiałby odpowiednio reprezentować potęgę rodu, zapraszać gości i sam bywać w gościach, a „kiedy które książę do siebie na obiad prosi, trzeba darować kuchmistrza, kucharza, kredencerza, piwniczego, trembaczów, bembnistów, komediantów, muzyków i inszych posługaczów, żeby czasem tu w ojczyźnie cały miesiąc na wychowanie ledwo tak wiele kosztowal, jako tam jednego obiadu przypłacić potrzeba. $\mathrm{W}$ miastach zaś przyślą honorarium konew wina, a trzeba posłu dać odużnego czerwony złoty i insze tym podobne, niewyliczone rozchody. Da księżna, która fawor od siebie albo od córki, bindę kitajkową haftowaną, trzeba posłowi odużnego, a paniej, albo pannie, podarek według stanu książęcego. A inaczej się nie godzi, więc kiedy tego będzie przez kilka lat, znaczny i wielki sumpt będzie" ${ }^{61}$. Koszty takiego życia z pewnością byłyby bardzo wysokie, a przecież Radziwiłłowi nie wypadało szczędzić na reprezentacji.

Jak młody Radziwiłł zdobędzie podstawy wiedzy w ojczyźnie, podrośnie, wzmocni się, przyjdzie czas na podróż. „A kiedy da Bóg, książę Janusz podroście, zbierze się z siłami i z rozumem, naukę będzie miał według lat i stanu swego, ćwiczenie w obyczajach i zabawach stanowi swemu należących, w ten czas nie z pacholęty, ale z ludźmi dojrzałymi w leciech i w rozumie, może jechać do cudzej ziemi i peregrynując poznać się stany cudzoziemskimi, przyjaźń zawrzeć, miastom, fortecom i wojskom się przypatrzyć, a za okazyją i specimen dzielności swej pokazać, odważywszy na to rok by i co więcej, i sumptu tego część, który przez lat kilka miał być ważony" ${ }^{62}$.

Na zakończenie swych rozważań nieznany autor przywołuje osobę Jana Zamoyskiego (1542-1605) i jego podejście do wychowania syna. „Ten syna swego w niedorosłych leciech w ojczyźnie chował i języków sąsiedzkich, ojczyźnie przyległych uczyć kazał. A potym, aż w osiemnastu leciech peregrynacyję odprawować testamentem rozkazał" ${ }^{63}$. Kanclerz w testamencie nakazał, aby syn nie wcześniej wyje-

\footnotetext{
60 Tamże.

61 Tamże.

62 Tamże.

63 Tamże, s. 197.
} 
chał aż „jego charakter nie zostanie wzmocniony” ${ }^{64}$, do dziewiętnastego roku życia młody Zamoyski miał uczyć się w założonej przez ojca akademii. Następnie „za radą opiekunów niech zakosztuje niebezpieczeństwa służby wojskowej”. I dopiero potem „za radą tych samych opiekunów wyjedzie za granicę czy to dla rozpoczęcia, czy to odnowienia, czy też dokończenia nauki. Jak powiedziałem - nie wyruszy jednak wcześniej, zanim jego charakter nie zostanie wzmocniony niebezpieczeństwami służby wojskowej”65. Faktycznie młody Zamoyski wyruszył w zagraniczne wojaże mając przeszło dwadzieścia lat ${ }^{66}$.

\section{Podsumowanie}

Przedstawiona instrukcja jest tekstem bardzo przemyślanym, dostrzec można dużą wiedzę i orientację autora w wielu aktualnych problemach, znajomość realiów podróżowania, wiedzę o rodzinie księcia. Można przypuszczać, że wiele podróżował oraz, że znana mu była literatura apodemiczna rozwijająca się od XVI w. i pokazująca zalety podróżowania w celach edukacyjnych. Wskazywałyby na to przedstawione na początku „pociechy i pożytki” wysłania młodego człowieka na nauki za granicę ${ }^{67}$.

Autor omawianych rozważań wyraźnie zdawał sobie sprawę ze znaczenia odpowiedniego wychowania młodego człowieka, dostrzegał prawidłowości rządzące rozwojem i uwarunkowania konkretnej osoby wynikające z wieku, kondycji fizycznej i sprawności intelektualnej. Wskazywał nie tylko czego i gdzie młody Radziwiłł powinien się uczyć, ale również w jaki sposób. Uważał, że najlepszym sposobem na zdobycie wiedzy w jakimś zakresie jest „ustawiczne używanie i częste czytanie”. Według niego nie powinno się nadmiernie przeciążać nauką dzieci, a kiedy można powinno się uczyć „grając i zabawiając”, wtedy dziecko „wiele rzeczy potrzebnych pojąć może”. Radził jak zorganizować naukę Janusza w ojczyźnie, aby skorzystali również inni młodzi ludzie, którzy tym samym nie musieliby szukać szkół poza granicami, ale mogli zdobywać potrzebną wiedzę w Rzeczypospolitej. Korzyści

\footnotetext{
64 Testament Jana Sariusza Zamoyskiego (1600), [w: ] Testamenty Jana, Tomasza i Jan „Sobiepana" Zamoyskich, oprac. W. Kaczorowski, Opole 2007, s. 35.

65 Tamże, s. 35-36.

66 A.A. Witusik, Peregrynacje zagraniczne Tomasza Zamoyskiego w latach 1615-1617, Annales Universitatis Mariae Curie-Skłodowska 25, (1970), 2, s. 27-47.

67 R. Dzięgielewski, Przygotowanie młodzieży do podróży akademickiej w XVI-XVIII wieku na przykładzie traktatów apodemicznych, w szczególności Brewiarza apodemicznego Gdańszczanina Samuela Zwickera, Gdańsk 2015.
} 
z proponowanych rozwiązań dotyczyłyby nie tylko potencjalnych współuczniów, ale także Radziwiłłów, którzy w ten sposób kształtowaliby grupę oddanych sobie ludzi, „animusze młodzi szlacheckiej ku książętom wprawowałyby się w miłość” pisze autor Konsyderacyji ${ }^{68}$.

W omawianych wskazówkach przedstawione zostały nie tylko pozytywne strony wyjazdów zagranicznych młodzieży, ale również ich negatywne strony. Autor nie skończył na krytyce, ale pokazał, co należy zrobić z młodym człowiekiem w sytuacji, w jakiej znajdował się Radziwiłł. Na zakończenie oferuje dalsze rady i pomoc. Nie uważa, że jest najlepszy, inni „snadniejsi” powinni się wypowiedzieć „o porządku w naukach, miejsce do mieszkania, sposobie wychowania" ${ }^{69}$, ale gdyby zaszła taka potrzeba, to i on może się znowu w tej materii wypowiedzieć.

Krzysztofa Radziwiłła przekonały argumenty zawarte w Konsyderacyjach, zostawił syna w ojczyźnie. Janusz przez kilka lat uczył się w domu, a następnie w szkole w Słucku pod opieką Adama Steckiewicza. Za granicę wyjechał, mając szesnaście lat, po „przyznaniu lat” przez ojca ${ }^{70}$. Na kolejne etapy edukacji spisane zostały odrębne instrukcje, jedna kiedy Janusz jechał do szkoły krajowej i kolejne przeznaczone na czas zagranicznych wojaży ${ }^{71}$.

\section{Summary}

Prince Krzysztof Radziwiłł wrote several recommendations for educating his only son by including instructions in his last will and other documents. He either did it himself or had someone from his entourage to write them down. Among these instructions is a text indicating the way in which the young prince was to be educated. The author recommended sending the boy to a school in the Polish-Lithuanian Commonwealth and, only when he would get older and gather strength and knowledge, to be sent to study abroad. The source material in question was probably written in 1622 by someone close to the prince.

The author lists the benefits of sending sons to study outside the Commonwealth first and then proves that this kind of trip at the age of 10 would have done the boy (Janusz) more harm than good. According to Krzysztof Radziwitl, at such a tender age a boy should be educated first in his home country. He could leave it only when he grew up, strengthened

\footnotetext{
68 Konsyderacyje, s. 195.

69 Tamże, s. 197.

70 Podróże Janusza omawia M. Chachaj, Zagraniczna edukacja, s. 75-84. Por. także D. Żołądź-Strzelczyk, Wskazówki wychowawcze dla Janusza Radziwitła.

71 Por. K. Radziwiłl, Wskazówki związane z edukacja syna Janusza w ojczyźnie i w cudzej ziemi (1622-1628), [w: ] Ojcowskie synom przestrogi, s. 175-244.
} 
physically, acquired basic knowledge and was ready to leave. The source contains considerations on how to organize the teaching of the prince's son, the curriculum and where to get the appropriate teachers.

Translated by Ewa Dratwa

Prof. dr hab. Dorota Żołądź-Strzelczyk

Zakład Historii Wychowania

Wydział Studiów Edukacyjnych

Uniwersytet im. Adama Mickiewicza w Poznaniu

ul. Szamarzewskiego 89

60-568 Poznań

e-mail: dorotagata@onet.pl

Nadesłany 10 I 2020

Nadesłany po poprawkach recenzyjnych 10 II 2020

Zaakceptowany 21 II 2020 